\title{
KONDISI KESESUAIAN PEMANFAATAN RUANG DI KOTA SURABAYA
}

\author{
Adhitama Jaya Kusuma ${ }^{1)}$, Anak Agung Sagung Alit Widyastuty. ${ }^{2)}$ \\ ${ }^{1) 2}$ Faklutas Teknik, Universitas PGRI Adi Buana Surabaya \\ Email: adhitamakusuma@gmail.com,
}

\begin{abstract}
Abstrak
Kecamatan Wonorejo dan Kecamatan Sukolilo merupakan bagian wilayah Kota Surabaya yang tergabung pada Unit Pengembangan (UP) II dalam dokumen RDTR Kota Surabaya tahun 2018 dengan kegiatan utama sebagai tempat permukiman, perdagangan, pendidikan, dan konservasi . Jenis kegiatan dan aktifitas yang sangat beragam menyebabkan pergesekan antara kebutuhan ruang terbangun dengan pemanfaatan ruang untuk konservasi. Tujuan dari penelitian ini adalah mengidentifikasi kesesuaian pemanfaatan ruang antara kondisi lapangan dengan RDTR serta faktor faktor yang menyebabkan penyimpangan pemanfaatan ruang, metode penelitian ini menggunakan adalah analisis spasial arithmetic overlay untuk mengidentifikasi kesesuaian pemanfaatan ruang dan analisis delphi untuk identifikasi faktor - faktor yang mempengaruhi perubahan pemanfaatan ruang berdasarkan stakeholders. Hasil dari kajian ini adalah Kesesuaian pemanfaatan ruang di UP II Kertajaya yaitu hanya sebesar 44\%. Pemanfaatan ruang dengan lahan terluas yang ada di UP II Kertajaya adalah tambak $1725 \mathrm{Ha}$ atau sebesar $42 \%$ yang pada rencana pemanfaatan ruang UP II Kertajaya nantinya akan dihilangkan karena tidak sesuai dengan tujuan kegiatan pengembangan di UP II Kertajaya. Faktor yang paling mempengaruhi kesesuaian lahan ada penambahan faktor yaitu aktifitas perekonomian dan infrastruktur. Hasil penarikan dari para expert menyatakan bahwa faktor paling tinggi yang mendasari rendahnya nilai kesesuaian pemanfaatan ruang di UP II kertajaya ini adalah nilai lahan, infrastruktur, pertumbuhan penduduk dan aktifitas perekonomian.
\end{abstract}

Keywords: Kesesuaian Pemanfaatan Ruang; Rencana Detail Tata Ruang Kota Surabaya tahun 2018; Unit pengembangan (UP) II.

\begin{abstract}
Wonorejo and Sukolilo Subdistrict are part of the Surabaya City region which is incorporated in the UP Development Unit II in the Surabaya City RDTR document in 2018 with the main activities as a place of settlement, trade, education and conservation. The types of activities and activities that are very diverse cause friction between the needs of the built space and the use of space for conservation. The purpose of this study is to identify the suitability of spatial use between field conditions with RDTR and the factors that cause irregularities in spatial use, the method used in this research is the spatial analysis of arithmetic overlay to identify the suitability of spatial use and delphi analysis to identify factors that influence utilization change space based on stakeholders. The result of this study is the suitability of space utilization in UP II Kertajaya, which is only 44\%. The use of space with the widest land available at UP II Kertajaya is a pond of 1725 ha or $42 \%$ which in the planned utilization of space for UP II Kertajaya will be eliminated because it is not in accordance with the objectives of the development activities in UP II Kertajaya. The factors that most influence land suitability are additional factors, namely economic activity and infrastructure. The results of the withdrawal from the experts stated that the highest factor underlying the low suitability value of space utilization in the UP II sector was the value of land, infrastructure, population growth and economic activity.
\end{abstract}

\section{PENDAHULUAN}

Perkembangan perkotaan yang seamakin pesat mengakibatkan tingginya angka pertumbuhan penduduk, yang mana merupakan permasalahan di perkotaan (Rachmawati \& Widyastuti, 2015). Kecamatan Wonorejo dan Kecamatan Sukolilo merupakan bagian wilayah Kota Surabaya sebagai kota dengan jumlah 
penduduk terbesar setelah DKI Jakarta, yang tergabung pada Unit Pengembangan (UP) wilayah II dalam dokumen Rencana Detail Tata Ruang Kota Surabaya. Kegiatan utama di Unit Pengembangan II adalah sebagai tempat permukiman, perdagangan, pendidikan, dan konservasi-RTH dengan pusat pertumbuhannya berada di Kertajaya Indah Dharmahusada Indah. Jenis kegiatan yang beragam membuat kebutuhan akan ruang untuk bangunan fisik (kegiatan permukiman, perdagangan, dan pendidikan) di Kecamatan Wonorejo dan Kecamatan Sukolilo menjadi tinggi, disamping itu kegiatan utama sebagai RTH-Konservasi juga memerlukan lahan yang bersifat terbuka sebagai upaya pemenrtahanan kualitas serta kelestarian lingkungan.

Bentuk pemanfaatan ruang sebagai lahan permukiman merupakan bentuk manifestasi dari kegiatan manusia untuk memanfaatkan ruang sebagai kebutuhan untuk tempat tinggal menurut Jihan (2015), serta dengan adanya rencana pembangunan Kawasan Kebun Raya Mangrove Kota Surabaya yang berada di pesisir pantai timur membutuhkan pengendalian mengenai pemanfaatan ruang di Kota Surabaya (Galih \& Tenola, 2018). Perencanaan kebun raya mangrove yang berupa lahan konservasi di Unit Pengembangan II Kota Surabaya ini merupakan ekosistem dari habitat hutan mangrove karena letaknya yang berada di pesisir timur Kota Surabaya yang juga menjadi habitat dari keberagaman flora dan fauna yang ada (Prihanto, 2011). Upaya mempertahankan lahan konservasi serta membangun lahan budidaya yang ideal dan sesuai arahan rencana merupakan permasalahan yang ada di UP II Kota Surabaya ini terlebih dengan jenis kegiatan utama yang begitu kompleks di wilayah ini.

Pengembangan lahan (land development) mencakup kegiatan yang berupa kegiatan peningkatan fisik lahan dan penyediaan prasarana sampai menjadi kawasan yang terbangun (Jihan, 2014). Perubahan dari fungsi pemanfaatan ruang yang tidak sesuai dengan Rencana Detail Tata Ruang Kota Surabaya akan menimbulkan tekanan kepada lingkungan sehingga kualitas dari lingkungan tersebut akan mengalami degradasi. Upaya pencegahan degradasi di lingkungan ini adalah dengan melakukan evaluasi dari pemanfaatan ruang yang ada (eksisting) dengan rencana dari pemenfaatan ruang di Rencana Detail Tata Ruang. Untuk itu perlunya diadakan evaluasi pemanfaatan ruang ini agar terciptanya lingkungan yang sehat dan berkelanjutan.

\section{METODE}

Penelitian "Kondisi Kesesuaian Pemanfaatan Ruang di Kota Surabaya" merupakan penelitian deskriptif evaluatif. penelitian ini menekankan pada penyajian data kesesuaian pemanfaatan ruang di UP II Kota Surabaya dari aspek atau fenomena yang sedang terjadi menggunakan analisis overlay. Lokasi penelitian dilakukan di Kota Surabaya dengan 2 wilayah administratif yaitu Kecamatan Mulyorejo dan Kecamatan Sukolilo yang tergabung dalam satu unit pengembangan yaitu Unit Pengembangan II.

Metode pengumpulan data yang digunakan dalam penelitian ini adalah survey sekunder dan survey primer. Surver primer pada penelitian ini dilakukan menggunakan dua cara yaitu kuisioner, observasi lapangan dan penginderaan jauh sedangkan survey sekunder berupa pengumpulan data yang diambil melalui instansi atau pemerintahan.

Cara mengetahui tingkat kesesuaian pemanfaatan ruang di UP II ini menggunakan metode analisis dekriptif kuantitatif dengan teknik analisis spasial arithmatatic overlay. Metode ini digunakan untuk mengenali hubungan spasial melalui proses overlay spatial pada Sistem Informasi Geografis (SIG) (Handayani \& Sunardi, 2005). Analisis Arithmetic Overlay digunakan untuk menangani peta dengan klasifikasi, hasilnya menunjukkan peta dengan klasifikasi baru dengan bantuan software ArcGIS dengan menumpukkan dua peta yaitu peta pemanfaatan ruang eksisting dengan peta rencana pola pemanfaatan ruang Unit Pengembangan II Kertajaya. Hasil overlay dari peta pemanfaatan ruang eksisting dengan peta pemanfaatan ruang berdasarkan Rencana Detail Tata Ruang akan dikelompokkan menjadi dua kategori yaitu sesuai atau tidak sesuai. Hasil ini dapat digunakan untuk mengetahui besaran luas penggunaan lahan, luas kesesuaian lahan, hingga luas dari tiap - 
tiap unit pemanfaatan ruang di Unit Pengembangan II Kota Surabaya (Rachman, 2012).

\section{HASIL DAN PEMBAHASAN}

Pemanfaatan ruang eksisting di wilayah UP II Kertajaya ini sangat beragam mulai dari tempat permukiman, perdagangan dan jasa, hingga ruang terbuka hijau. Hal ini disebabkan oleh kompleksnya kebutuhan masyarakat di Surabaya khususnya di UP II Kertajaya. Penggunaan lahan dengan wilayah terluas di UP II Kertajaya berupa tambak yaitu 50,66 \% dari luas keseluruhan 2007,126 Ha, sedangkan penggunaan lahan dengan luas paling sedikit yaitu zona perkantoran dengan luas $0,003 \%$ atau $13,520 \mathrm{Ha}$. Sub-zona sarana transportasi dan zona pergudangan dengan luas $0,004 \%$ atau 0,149 Ha dan 0,147 Ha merupakan zona dengan luas terendah setelah zona perkantoran. Zona transportasi di UP II Kertajaya ini merupakan sarana transportasi berupa terminal di Jalan Raya Keputih, Kelurahan Keputih, Kecamatan Sukolilo. Terminal Keputih merupakan terminal dengan tipe terminal penumpang $\mathrm{C}$ yang berfungsi berfungsi melayani kendaraan umum kelas kecil seperti angkutan kota dan angkutan pedesaan. Pemanfaatan ruang sebagai tambak sangat dominan di UP II Kertajaya hal ini dipangaruhi oleh letak geografisnya yang berdekatan dengan laut atau lebih tepatnya berada di pesisir pantai timur Kota Surabaya sehingga banyak masyarakat yang memanfaatkan lahannya sebagai lahan tambak. Selain sebagai lahan tambak pengunaan sebagai perumahan juga cukup tinggi hal ini disebabkan oleh fungsi kegiatandari UP II Kertajaya itu sendiri berupa daerah permukiman. Perdagangan dan jasa yang merupakan penggunaan lahan yang terluas setelah tambak dan perumahan yaitu seluas 1050,694 Ha atau 26,5\%. Kondisi pemanfaatan ruang eksisting dapat dilihat pada gambar 1.
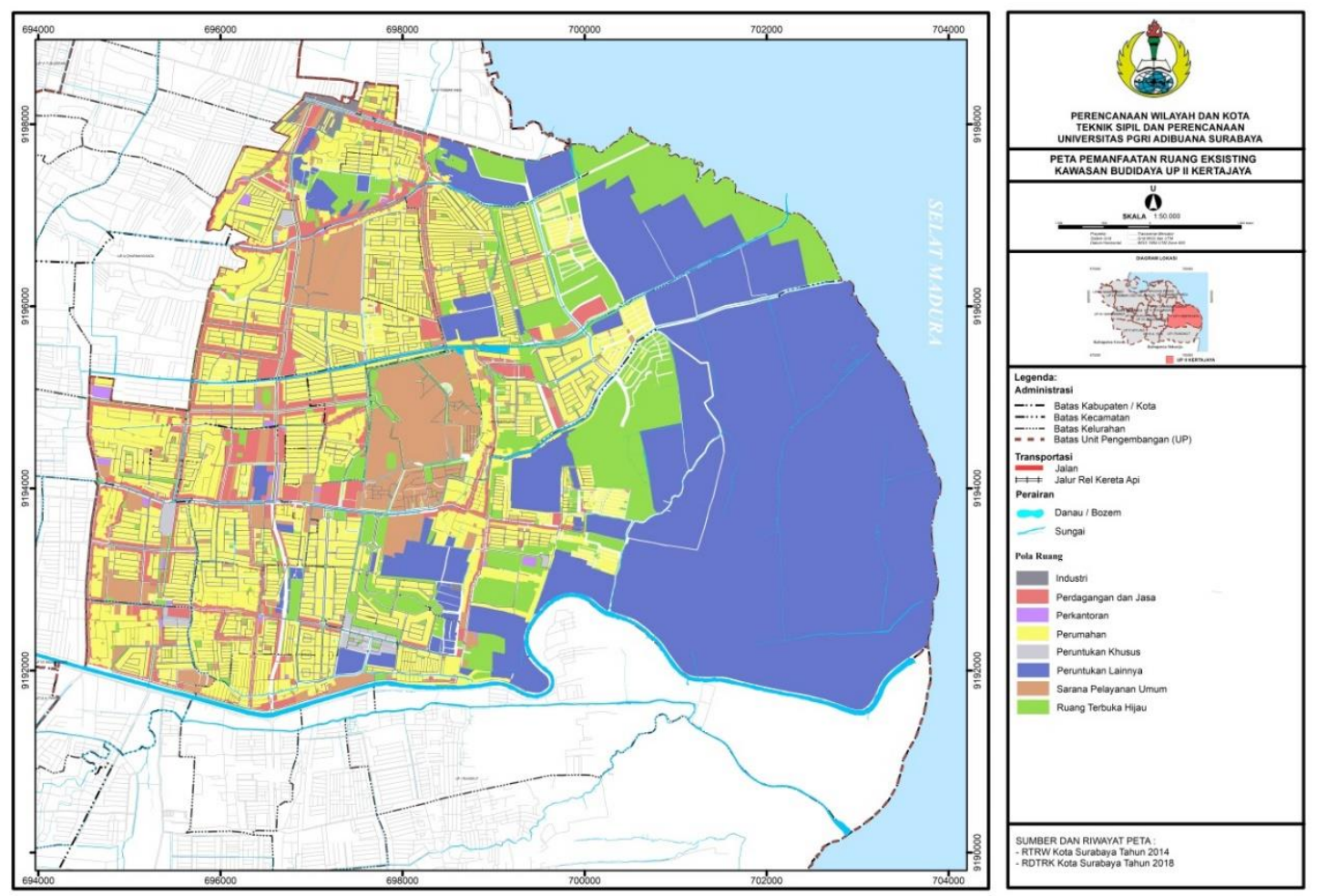

Gambar 1. Peta Pemanfaatan Ruang Eksisting UP II Kertajaya

Rencana pola ruang pada UP II berdasarkan Peraturan Daerah No 8 Tahun 2018 terbagi menjadi dua yaitu rencana zona lindung dan rencana zona budidaya. Rencana zona lindung dalam pasal 33 berisi mengenai Rencana zona perlindungan terhadap kawasan bawahnya (PB) yang berupa sub zona 
waduk/bozem (PB-2) dengan luas 23,91 ha yang dimanfaatkan sebagai RTH public.

Rencana zona perlindungan setempat (PS) pada pasal 35 dengan luas keseluruhan $1.463,02$ ha yang terbagi kedalam sub zona sempadan pantai (PS-1) dengan luas 5,88 Ha, sempadan sungai (PS-2) dengan luas 5,88 $\mathrm{Ha}$.

Perlindungan setempat sempadan waduk/bozem (PS-3) dengan luas 2,20 Ha, dan sempadan SUTT/SUTET (PS-4) dengan luas 3,70 Ha yang dimanfaatkan sebagai RTH publik. (RTH) dalam pasal 36 dengan luas keseluruhan 164,81 Ha yang terbagi kedalam sub zona taman dan lapangan (RTH-1) dengan luas 53,69 Ha. Rencana sub zona jalur hijau (RTH-2) dengan luas 58,51 Ha. Rencana sub zona makam (RTH-3) dengan luas 52,60 Ha.

Rencana zona budidaya sebagaimana diatur dalam pasal 37 terdiri dari rencana sebagai berikut :

1) Rencana zona perumahan (R) dengan luas $1.507,95$ Ha terbagi kedalam sub zona perumahan kepadatan tinggi (R-2) dengan luas 667,19 ha.

2) Rencana sub zona perumahan kepadatan sedang (R-3) dengan luas $533,74 \mathrm{Ha}$

3) Rencana sub zona perumahan kepadatan rendah (R-4) dengan luas 307,01 Ha

4) Rencana zona perdagangan dan jasa $(\mathrm{K})$ dengan luas keseluruhan 349,09 Ha yang terbagi kedalam sub zona perdagangan dan jasa skala regional/kota/UP (K-5) dengan luas 175,93 Ha. Rencana sub zona perdagangan dan jasa skala lokal/lingkungan (K-6) dengan luas 173, 15 Ha.

5) Rencana zona perkantoran (KT) berupa rencana sub zona perkantoran pemerintahan (KT-1) dengan luas 13,69 ha.

6) Rencana zona sarana pelayanan umu (SPU) dengan luas keseluruhan 355,42 ha terbagi kedalam sub zona sarana pelayanan umum pendidikan (SPU-1) dengan luas 284,83 ha. Rencana sub zona sarana pelayanan umum transportasi (SPU-2) dengan luas 1,97 ha. Rencana sub zona sarana pelayanan umum kesehatan (SPU-3) dengan luas 10,97 ha. Rencana sub zona sarana pelayanan umum olahraga (SPU-4) dengan luas 5,08 ha. Rencana sub zona sarana pelayanan umum sosial budaya (SPU-5) dengan luas 22,32 ha. Rencana sub zona sarana pelayanan umum peribadatan (SPU-6) dengan luas 13,98 ha. Dan rencana sub zona sarana pelayanan umum lainnya (SPU-7) dengan luas 16,27 ha.

7) Rencana zona industri (I) yang berupa sub zona aneka industri (I-4) dengan luas 10,46 Ha.

8) Rencana zona khusus (KH) dengan luas 77,46 ha yang terbagi kedalam sub zona pertahanan dan keamanan (KH-1) dengan luas 69,68 ha yang berada di Sub UP II-A Blok II-A1 dan sub zona instalasi utilitas (KH-5) dengan luas 7,78 ha.

Rencana pemanfaatan ruang di P II Kertajaya dapat dilihat pada gambar 2.

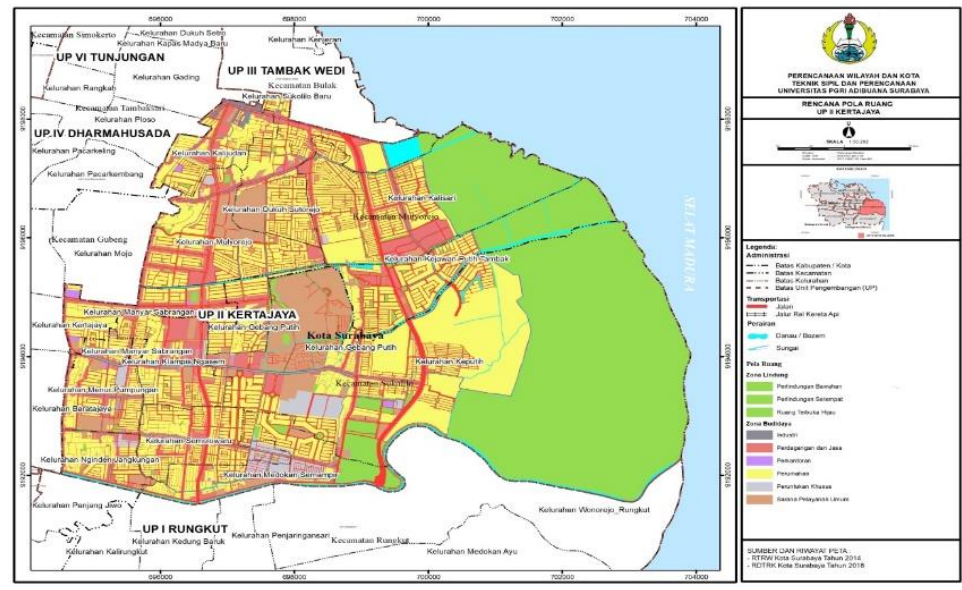

Gambar 2. Rencana Pemanfaatan Ruang UP II Kertajaya Menurut RDTRK Kota Surabaya Tahun 2018-2038 
Analisa kesesuaian pemanfaatan ruang menggunakan metode analisis arithmetic overlay dengan menumpang tindihkan dua peta yaitu peta pemanfaatan ruang eksisting dengan peta pemanfaatan ruang rencana berdasarkan RDTRK Kota Surabaya. Dari hasil overlay tersebut kemudian dapat diketahui seberapa besar tingkat kesesuaian pemanfaatan ruang di UP II Kertajaya ini. Jenis pemanfaatan ruang yang ada di UP II Kertajaya baru $42,8 \%$ yang bisa dikatakan sesuai atau sebanyak 6 (enam) jenis pemanfaatan ruang yaitu industri dengan nilai kesesuaian $108 \%$, perkantoran dengan nilai kesesuaian $148 \%$, sarana kantor pemerintahan dan sarana olahraga dengan nilai kesesuaian $100 \%$, sarana kesehatan dengan nilai kesesuaian $433 \%$ dan sarana peribadatan dengan nilai $147 \%$. Jenis pemanfaatan ruang pergudangan dan peruntukan lainnya tidak terdapat dalam rencana pemanfaatan ruang UP II Kertajaya sehingga nilai kesesuaiannya dianggap tidak sesuai.

Tabel 1. Kesesuaian Pemanfaatan Ruang di UP II Kertajaya

\begin{tabular}{|lrrl}
\hline \multirow{1}{*}{ Pemanfaaatan Ruang } & \multicolumn{2}{c}{ Luas } & Kesesuaian \\
\hline Industri & Rencana & Eksisting & \\
Perdagangan dan Jasa & 10,459 & 11,26219 & Sesuai \\
Pergudangan & 339,8293 & 260,175 & Tidak Sesuai \\
Perkantoran & 0 & 0,147104 & Tidak Sesuai \\
Perumahan & 13,389 & 13,520 & Sesuai \\
Peruntukan Khusus & 1518,562 & 1050,694 & Tidak Sesuai \\
RTH & 77,092 & 22,478 & Tidak Sesuai \\
Sarana Kantor Pemerintah & $1.644,94$ & 249,622 & Tidak Sesuai \\
Sarana Kesehatan & 0,136 & 0,136 & Sesuai \\
Sarana Olahraga & 16,22 & 16,216 & Sesuai \\
Sarana Pendidikan & 5,429 & 5,429 & Sesuai \\
Sarana Peribadatan & 283,774 & 283,774 & Sesuai \\
Sarana Pelayanan Lainnya & 14,288 & 20,955 & Sesuai \\
Sarana Sosial Budaya & 12,935 & 5,711 & Tidak Sesuai \\
Sarana Transportasi & 22,4809 & 14,461 & Tidak Sesuai \\
Peruntukan Lainnya & 2,319 & 0,149 & Tidak Sesuai \\
\hline \hline
\end{tabular}

Kesesuaian pemanfaatan ruang di UP II Kertajaya adalah $43,75 \%$ sedangkan yang belum sesuai adalah 56,25\%. Pemanfaatan ruang dengan nilai kesesuaian paling rendah adalah sarana transportasi dengan nilai $8 \%$ dan peruntukan khusus dengan nilai $29 \%$. Pemanfaatan ruang eksisting didominasi oleh peruntukan lainnya berupa tambak dengan luas $1724,453 \mathrm{Ha}$ atau sebesar $42,38 \%$ dari luas keseluruhan yang seharusnya untuk lahan terbangun seperti perumahan dan kawasan lindung berupa sempadan pantai. Pemanfaatan ruang rencana berdasarkan RDTRK UP II Kertajaya didominasi oleh RTH dengan luas $1648,426 \mathrm{Ha}$ atau seluas $40,62 \%$ dari luas keseluruhan, yang pada kondisi eksisting sebagian besar lahannya masih digunakan untuk peruntukan lainnya berupa tambak. Peta kesesuaian pemanfaatan ruang di UP II Kertajaya merupakan hasil overlay dari peta pemanfaatan ruang eksisting dengan peta rencana pemanfaatan ruang dengan alur pada gambar 3. 
Peta Pemanfaatan Ruang Eksisting

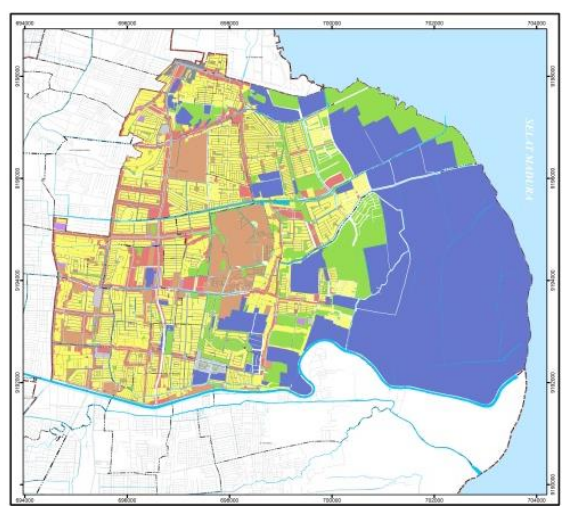

Peta Rencana Pemanfaatan Ruang
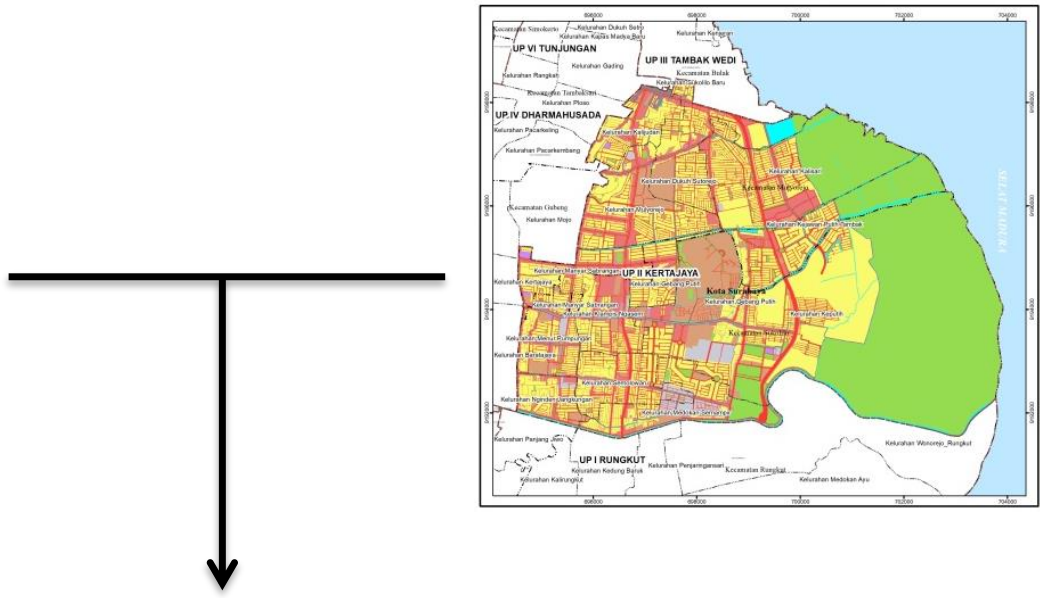

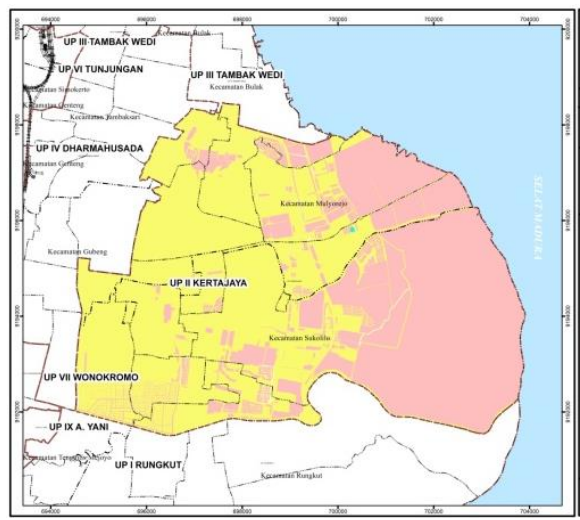

Peta Kesesuaian Pemanfaatan Ruang

\section{Gambar 3. Alur Analisa Overlay Peta Kesesuaian Pemanfaatan Ruang UP II Kertajaya}

Hasil analisa menyimpulkan area yang sesuai dan tidak sesuai antara kondisi pemanfaatan ruang eksisting dengan rencana pemanfaatan ruang di UP II Kertajaya, sehingga dapat diketahui pemanfaatan ruang eksisting apa saja yang tidak sesuai dengan rencananya. Pembahasan kesesuaian pemanfaatan ruang terbagi menjadi beberapa zona, yaitu :

\section{a. Zona Industri}

Kondisi kesesuaian pemanfaatan ruang zona industri melebihi nilai $100 \%$ yang berarti kondisi pemanfaatan ruang eksisting lebih luas $(0,803 \mathrm{Ha})$ dari pada luas rencana pemanfaatan ruangnya. Luas rencana pemanfaatan ruang zona industry di UP II Kertajaya mengalami penyusutan dikarenakan adanya rencana pengembangan jaringan jalan.

\section{b. Zona Perdagangan dan Jasa}

Tingkat kesesuaian antara
pemanfaatan ruang eksisting dan
pemanfaatan ruang rencana zona
perdagangan dan jasa bernilai $76,6 \%$.
Ketidak sesuaian pemanfaatan ruang ini
dipengaruhi oleh beragmnya pemanfaatan
ruang yang ada (eksisting).untuk lebih
jelasnya dapat dilihat pada tabel 2.


Tabel 2. Analisa Overlay Pemanfaatan Ruang Perdagangan dan Jasa

\begin{tabular}{cclrr}
\hline \hline \multirow{2}{*}{ Zona } & $\begin{array}{c}\text { Luas Lahan } \\
\text { Rencana (Ha) }\end{array}$ & \multicolumn{1}{c}{ Eksisting } & $\begin{array}{r}\text { Pemanfaatan Ruang } \\
\text { Luas Lahan (Ha) }\end{array}$ & Persentase \\
\hline \hline & Lahan Kosong & 47,279 & $13,9 \%$ \\
& Perdagangan dan Jasa & 260,175 & $76,6 \%$ \\
& & Perumahan & 6,038 & $1,8 \%$ \\
Perdagangan & \multirow{2}{*}{339,8293} & RTH & 5,737 & $1,7 \%$ \\
dan Jasa & & Sarana Sosial Budaya & 0,125 & $0,0 \%$ \\
& & Sarana Kesehatan & 0,819 & $0,2 \%$ \\
& & Sarana Pendidikan & 0,001 & $0,0 \%$ \\
& & Tambak & 19,654 & $5,8 \%$ \\
\hline \hline
\end{tabular}

\section{c. Zona Perkantoran}

Pemanfaatan ruang perkantoran di UP II Kertajaya tingkat kesesuaian $100 \%$ yang berarti kondisi luas pemanfaatan eksisting lebih luas daripada kondisi luas pemanfaatan rencana RDTRK. Hal ini disebabkan karena adanya pengembangan ruang milik jalan (rumija) pada jalan Arief Rahman Hakim dan Jalan Kalisari - Jalan Sutorejo - Jalan Mulyorejo berupa pembangunan box culvert diatas saluran drainase sama seperti pemanfaatan ruang industri. Dampak dari pengembangan rumija ini mengakibatkan $0,131 \mathrm{Ha}$ lahan perkantoran harus di bebaskan.

\section{d. Zona Perumahan}

Tingkat kesesuaian pemanfaatan ruang zona perumahan di UP II Kertajaya adalah $69,2 \%$ atau seluas 1050,694 Ha, Pemanfaatan ruang lahan kosong serta tambak merupakan salah satu bagian pemanfaatan ruang yang menggunakan lahan peruntukan perumahan paling luas diantara pemanfaatan ruang yang lainnya. Hal ini dijabarkan ada tabel 3. Yang menjelaskan eksisting dari oemanfaatan ruang perumahan

Tabel 3. Analisa Overlay Pemanfaatan Ruang Perumahan

\begin{tabular}{cclrr}
\hline \hline \multirow{2}{*}{ Zona } & $\begin{array}{c}\text { Luas Lahan } \\
\text { Rencana (Ha) }\end{array}$ & \multicolumn{1}{c}{ Eksisting } & $\begin{array}{c}\text { Pemanfaatan Ruang } \\
\text { Luas Lahan (Ha) }\end{array}$ & Persentase \\
\hline \hline \multirow{4}{*}{ Perumahan } & \multirow{2}{*}{1518,562} & Lahan Kosong & 194,315 & $12,8 \%$ \\
& & Perdagangan dan Jasa & 1,458 & $0,1 \%$ \\
& & Perumahan & 1050,694 & $69,2 \%$ \\
& & RTH & 12,346 & $0,8 \%$ \\
& & Sarana Kesehatan & 1,743 & $0,1 \%$ \\
& & Sarana Pendidikan & 0,003 & $0,0 \%$ \\
& & Tambak & 258,003 & $17,0 \%$ \\
\hline \hline
\end{tabular}

\section{e. Zona Peruntukan Khusus}

Tingkat kesesuaian pemanfaatan ruang zona peruntukan khusus di UP II Kertajaya adalah 29,2\% atau seluas 22,478 Ha. Pemanfaatan ruang perumahaan mendominasi area pemanfaatan peruntukan khusus diantara pemanfaatan ruang lainnya. 
Tabel 4. Analisa Pemanfaatan Ruang Peruntukan Khusus

\begin{tabular}{|c|c|c|c|c|}
\hline \multirow{2}{*}{ Zona } & \multirow{2}{*}{$\begin{array}{c}\text { Luas Lahan } \\
\text { Rencana (Ha) }\end{array}$} & \multicolumn{3}{|c|}{ Pemanfaatan Ruang } \\
\hline & & Eksisting & Luas Lahan (Ha) & Persentase \\
\hline \multirow{6}{*}{$\begin{array}{l}\text { Peruntukan } \\
\text { Khusus }\end{array}$} & \multirow{6}{*}{77,092} & Lahan Kosong & 1,480 & $1,9 \%$ \\
\hline & & Perdagangan dan Jasa & 0,057 & $0,1 \%$ \\
\hline & & Perumahan & 10,444 & $13,5 \%$ \\
\hline & & Peruntukan Khusus & 22,478 & $29,2 \%$ \\
\hline & & $\mathrm{RTH}$ & 3,067 & $4,0 \%$ \\
\hline & & Tambak & 39,566 & $51,3 \%$ \\
\hline & Jumlah & & 77,09175 & $100 \%$ \\
\hline
\end{tabular}

\section{f. Zona Ruang Terbuka Hijau}

Kondisi kesesuaian ruang terbuka hijau di UP II Kertajaya tidak terlalu besar, yaitu $15,18 \%$ atau seluas 129,622 Ha. Pemanfaatan ruang sebagai tambak mendominasi area untuk rencana pemanfaatan ruang sebagai ruang terbuka hijau yaitu seluas $1.370,65 \mathrm{Ha}$ atau sebesar $83,33 \%$ untuk peruntukan ruang terbuka hijau.

Tabel 5. Analisa Overlay Pemanfaatan Ruang RTH

\begin{tabular}{cclrr}
\hline \hline \multirow{2}{*}{ Zona } & Luas Lahan & \multicolumn{3}{c}{ Pemanfaatan Ruang } \\
& Rencana (Ha) & \multicolumn{1}{c}{ Eksisting } & Luas Lahan (Ha) & Persentase \\
\hline \hline & & Lahan Kosong & 17,236 & $1,05 \%$ \\
Ruang & & Perdagangan dan Jasa & 0,354 & $0,02 \%$ \\
Terbuka & \multirow{2}{*}{1644,942} & Perumahan & 6,744 & $0,41 \%$ \\
Hijau & RTH & 249,622 & $15,18 \%$ \\
& & Sarana Sosial Budaya & 0,336 & $0,02 \%$ \\
& & Tambak & 1370,650 & $83,33 \%$ \\
\hline \hline
\end{tabular}




\section{g. Zona Sarana Pelayanan Umum}

Pemanfaatan ruang zona sarana pelayanan umum di UP II Kertajaya terbagi kedalam 8 (delapan) sub zona kawasan yaitu :

\section{a) Sub-Zona Sarana Kantor Pemerintahan}

Sarana kantor pemerintahan di UP II Kertajaya memiliki nilai kesesuaian $100 \%$ hal ini disebabkan karena tidak ada rencana penambahan kantor pemerintahan di UP II Kertajaya.

b) Sub-Zona Sarana Kesehatan

Sarana kesehatan di UP II Kertajaya memiliki nilai kesesuaian 99,98\%. Rencana pemanfaatan ruang di UP II Kertajaya pada sarana kesehatan khususnya kegiatan apotek dikategorikan kedalam pemanfaatan ruang perdagangan dan jasa. Puskesmas di UP II Kertajaya juga tidak semua ada di rencana pemanfaatan ruang UP II Kertajaya.

Tabel 6. Analisa Pemanfaatan Ruang Sarana Kesehatan

\begin{tabular}{|c|c|c|c|c|}
\hline \multirow[b]{2}{*}{ Zona } & \multirow{2}{*}{$\begin{array}{c}\text { Luas Lahan } \\
\text { Rencana }\end{array}$} & \multicolumn{3}{|c|}{ Pemanfaatan Ruang } \\
\hline & & Eksisting & $\begin{array}{c}\text { Luas Lahan } \\
\text { (Ha) }\end{array}$ & Persentase \\
\hline \multirow[t]{2}{*}{ SaranaKesehatan } & \multirow[t]{2}{*}{16,22} & $\begin{array}{l}\text { Sarana Kesehatan } \\
\text { Sarana }\end{array}$ & 16,216 & $99,98 \%$ \\
\hline & & Pendidikan & 0,003 & $0,02 \%$ \\
\hline & Jumlah & & 16,220 & $100 \%$ \\
\hline
\end{tabular}

\section{c) Sub-Zona Sarana Olahraga}

Sarana olahraga di UP II Kertajaya memiliki kesesuaian $100 \%$ hal ini disebabkan tidak adanya rencana penambahan sarana olahraga di UP II Kertajaya. Kondisi rencana pemanfaatan ruang dan kondisi di lapangan juga sudah sesuai.

\section{d) Sub-Zona Sarana Pendidikan}

Sarana pendidikan UP II Kertajaya memiliki kesesuaian $100 \%$ hal ini disebabkan tidak adanya penambahan sarana pendidikan di UP II Kertajaya. Kondisi rencana pemanfaatan ruang dan kondisi di lapangan juga sudah sesuai.

e) Sub-Zona Sarana Peribadatan
Sarana peribadatan di UP II Kertajaya memiliki nilai kesesuaian $147 \%$ hal ini dikarenakan luas pemanfaatan ruang eksisiting untuk sarana perbibadatan lebih luas dari pada rencana pemanfaatan ruangnya. Pada rencana pemanfaatan ruang sarana peribadatan tidak mencakup sarana mushola, sedangkan pada rencana pemanfaatan ruang mushola termasuk kedalam pemanfaatan sarana pelayanan umum lainnya dengan luas 6,667 Ha.

f) Sub-Zona Sarana Pelayanan Umum Lainnya

Kondisi kesesuaian pemanfaatan ruang sarana pelayanan umum di UP II Kertajaya bernilai $44,2 \%$ atau seluas $5,711 \mathrm{Ha}$ dengan luas lahan rencana yaitu $12,935 \mathrm{Ha}$. 
Tabel 7. Analisa Overlay Pemanfaatan Ruang Sarana Pelayanan Umum lainnya

\begin{tabular}{cclrr}
\hline Zona & $\begin{array}{c}\text { Luas Lahan } \\
\text { Rencana (Ha) }\end{array}$ & Eksisting & $\begin{array}{c}\text { Pemanfaatan Ruang } \\
\text { Luas Lahan } \\
\text { (Ha) }\end{array}$ & Persentase \\
\hline \hline & & Lahan Kosong & 4,209 & $32,5 \%$ \\
Sarana & & Perumahan & 0,025 & $0,2 \%$ \\
Pelayanan & \multirow{2}{*}{12,935} & RTH & 0,628 & $4,9 \%$ \\
Umum & & SPU Lainnya & 5,711 & $44,2 \%$ \\
Lainnya & & Tambak & 2,362 & $18,3 \%$ \\
\hline & & & $\mathbf{1 2 , 9 3 4 9}$ & $\mathbf{1 0 0 \%}$ \\
\hline
\end{tabular}

g) Sub-Zona Sarana Sosial Budaya

Kondisi kesesuaian pemanfaatan ruang sarana sosial budaya di UP II Kertajaya bernilai $64,3 \%$ atau seluas 14,461 Ha. Pemanfaatan ruang eksisting yang mendominasi adalah lahan kosong dengan luas $6,071 \mathrm{Ha}$ atau sebsesar $27 \%$.

Tabel 8. Analisa Pemanfaatan Ruang Sarana Sosial Budaya

\begin{tabular}{cllrr}
\hline \hline Zona & $\begin{array}{c}\text { Luas Lahan } \\
\text { Rencana }\end{array}$ & \multicolumn{1}{c}{ Eksisting } & $\begin{array}{c}\text { Pemanfaatan Ruang } \\
\text { Luas Lahan } \\
\text { (Ha) }\end{array}$ & Persentase \\
\hline & & Lahan Kosong & 6,071 & $27,0 \%$ \\
Sarana & Perumahan & 0,414 & $1,8 \%$ \\
Sosial & \multirow{2}{*}{22,4809} & RTH & 0,825 & $3,7 \%$ \\
Budaya & & Sarana Sosial & 14,461 & $64,3 \%$ \\
& & Budaya & 0,710 & $3,2 \%$ \\
\hline \hline & & Tambak & $\mathbf{2 2 , 4 8 0 9}$ & $\mathbf{1 0 0 \%}$ \\
\hline \hline
\end{tabular}

h) Sub-Zona Sarana Transportasi

Kondisi kesesuaian pemanfaatan ruang sarana transportasi si UP II Kertajaya bernilai
$6,4 \%$ atau seluas 0,149 Ha. Pemanfaatan ruang yang mendominasi adalah lahan kosong dengan luas 1,922 Ha atau sebesar 82,9\%

Tabel 9. Analisa Overlay Pemanfaatan Ruang Sarana Transportasi

\begin{tabular}{lllrr}
\hline \hline \multirow{2}{*}{ Zona } & \multirow{2}{*}{$\begin{array}{c}\text { Luas Lahan } \\
\text { Rencana (Ha) }\end{array}$} & \multicolumn{3}{c}{ Pemanfaatan Ruang } \\
& Eksisting & $\begin{array}{c}\text { Luas Lahan } \\
\text { (Ha) }\end{array}$ & Persentase \\
\hline \multirow{3}{*}{ Transportasi } & \multirow{2}{*}{2,319} & Lahan Kosong & 1,922 & $82,9 \%$ \\
& & Perumahan & 0,181 & $7,8 \%$ \\
& & RTH & 0,067 & $2,9 \%$ \\
& & Transport & 0,149 & $6,4 \%$ \\
\hline & \multirow{2}{*}{ Jumlah } & & $\mathbf{2 , 3 1 9}$ & $\mathbf{1 0 0 \%}$ \\
\hline
\end{tabular}

Hasil analisa kesesuaian pemanfaatan ruang di UP II Kertajaya dapat dilihat secara visual melalui peta kesesuaian pemanfaatan ruang pada gambar 4 . 


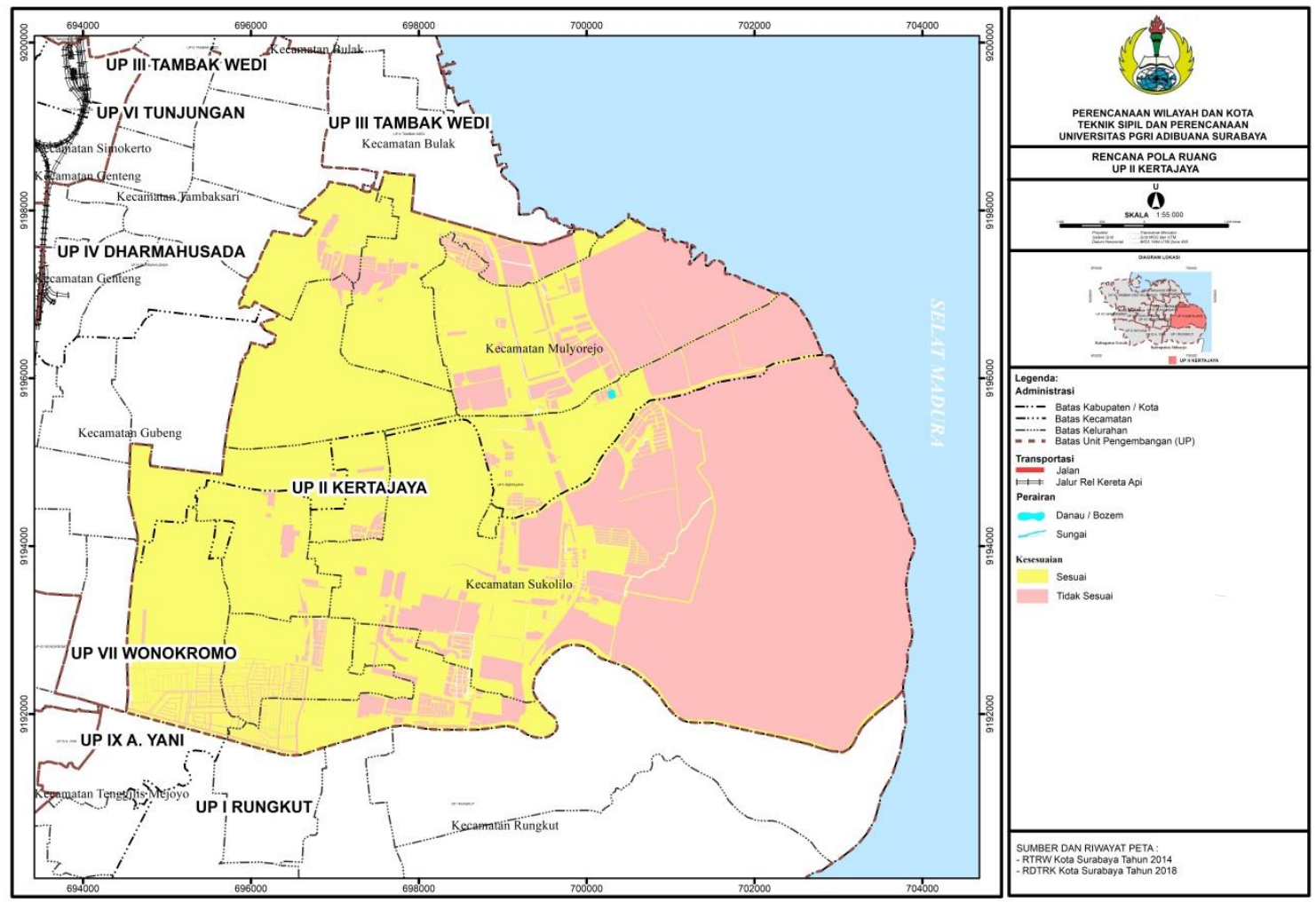

Gambar 4. Peta Kesesuaian Pemanfaatan ruang di UP II Kertajaya

\section{KESIMPULAN}

Kesesuaian pemanfaatan ruang yang berubah seiring beragamnya kebutuhan ruang bagi masyarakat hal ini dapat terjadi seiring dengan peningkatan jumlah penduduk. Pemafaatan ruang juga tidak melulu mengenai zona - zona dengan beragam kegiatan masyarakat didalamnya, namun juga kualitas dan kelestarian dari lingkungan itu sendiri perlu diperhatikan. Nilai kesesuaian pemanfaatan ruang di UP II Kertajaya yaitu sebesar $43,75 \%$. Pemanfaatan ruang dengan lahan terluas yang ada di UP II Kertajaya adalah tambak 1724,453 Ha atau sebesar $42,38 \%$ yang pada rencana pemanfaatan ruang UP II Kertajaya nantinya akan dihilangkan karena tidak sesuai dengan tujuan kegiatan pengembangan di UP II Kertajaya. Penyebab terjadinya ketidaksesuaian pemanfaatan ruang di UP II Kertajaya ini disebabkan oleh ketidakseimbangan antara pemanfaatan ruang perkotaan dengan kebutuhan ruang untuk masyarakat. Hal ini dikarenakan dinamika perkembangan perkotaan yang disebabkan oleh proses urbanisasi (Rukmana \& Widyastuti, 2018).

\section{UCAPAN TERIMAKASIH}

Ucapan terimakasih ditujukan kepada Pemerintah Kota Surabaya yang telah memberikan bantuan berupa data - data yang diperlukan selama penelitian berlangsung.

\section{DAFTAR PUSTAKA}

Galih, A., \& Tenola, D. (2018). Pembangunan Kebun Raya Mangrove Akan Dimulai Bulan Depan, pp. 1-5.

Handayani, D., \& Sunardi. (2005). Pemanfaatan Analisis Spasial untuk Pengelolahan Data Spasial Sistem Informasi Geografi. Jurnal Teknologi Informasi DINAMIK, $X$.

Jihan, J. C. (2014). Analisa Zona Perubahan Penggunaan Lahan Di Kecamatan Sukolilo Surabaya Timur Berbasis SIG. Institut Teknologi Sepuluh Nopember.

Jihan, J. C. (2015). Pemanfaatan Global Navigation Satellite System ( GNSS ) Untuk Pemetaan Penggunaan Lahan Di Kecamatan Sukolilo Surabaya Timur. Prosiding Seminar Nasional ReTII, 
$154-160$.

Prihanto, T. (2011). Kajian Daya Dukung Ruang Terbuka Hijau Terhadap Kinerja Gedung Kampus Konservasi. Jurnal Teknik Sipil Dan Perencanaan, 13(2), 131-140.

Rachman, G. (2012). Merancang Akses dan Asesmen Pendidikan Berbasis Konsep Sistem Informasi dan Geografis (SIG) di Kabupaten Buru Selatan Provinsi Maluku. Bimafika, 4, 480-487.
Rachmawati, S. D., \& Widyastuti, A. A. S. A. (2015). Status Kepemilikan Lahan Pendukung Pertumbuhan. Jurnal Teknik Waktu, 13, 54-62.

Rukmana, S. N., \& Widyastuti, A. A. S. A. (2018). Towards Sustainable Development : Resource Approach Through Interaction of Peri-urban And Surrounding Areas. Earth and Environtmental, 202. 